\title{
Formulation, Stability and Bioequivalency Study of Prepared Salbutamol Sulphate Nebules.
}

Bazigha K. Al-Temimy, Alaa A. Abdul-Rasool Received: 07.01.2001

Accepted: 2.3.10.2002

\section{ABSTRACT:}

Salbutamol sulphate nebules is considered as the most rapid effective route of administration for treatment of acute attacks of asthma .

This study was carried out to formulate a stable formula of salbutamol nebules containing $0.1 \%(2.5 \mathrm{mg} / 2.5 \mathrm{ml})$ of the active ingredient in a buffered solution . Stability study in different buffers at $\mathrm{pH} 3$ showed that the longest shelf life was equal to 3.5 years for formula $\mathrm{F}$.In addition the bioequivalency of this formula incomparison to ventolin ${ }^{\circledR}$ nebules was measured and it was equal to $( \pm 5.2) \%$.

Also it was found that there was no significant difference between the formula and ventolin ${ }^{\circledR}$ nebules regarding their pharmacokinetic parameters which include elimination rate constant, elimination $t 0.5$ and amount of the unchanged drug excreted in urine, $30 \mathrm{~min}$. after administration $(\mathrm{p}<0.05)$. This study may suggest that the prepared formula could be used successfully in the preparation of salbutamol sulphate nebules.

ان رذاذ السالبيوتامول سلفيت يعتبر الطريق الاسرع و الاكثر فعاليـة في علاج النوبـات الحساذة التي تصيب

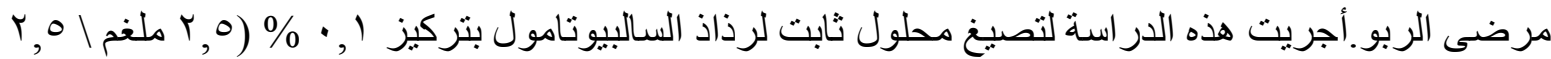
مل ) للمادة الفعالة في المحلول الدارىء ـاظهرت در اسة ثباتية سلفات السالبيوتامول في عدة محاليل در ائة عند أس هيدروجيني ح, r ان اطول عمر لانتهاء مفعول الدواء يساوي م, r سنة للصيغة التركيبية (ف) . أضـافة لهذا فلقد تم قيـاس التكافؤ الحيوي للصيغة التركيبية (ف) مقارنـة بالمستحضر التجاري رذاذ الفنتولين وكانت مساوية الى 9 \% \% ( Y Y, ).كذللك فلقد وجد ان لكليهما نفس مقاييس حركية الدواء و المتضمنة ثابت سرعة الطرح ,نصف عمر الطرح وكمية الدواء الغير متغير و المطروح خلال . بـ دقيقة من أخذ العلاج .أن هـذه الدر اسـة تقتـر ح ان الصـيغة التركيبيـة المحضـرة (ف) يمكـن اسـتعمالها بنجــاح لتحضـير رذاذ سـلفات 


\section{INTRODUCTION:}

Salbutamol is a beta-adrenergic stimulant that has a selective action on beta-2adrenoceptors in the bronchi and uterus. It is available in a variety of dosage forms such as injections, tablets, syrups, aerosols and nebules ${ }^{(1,2)}$.

Inhalation of salbutamol sulphate via a nebulizer is an integral component of modern treatment of airway diseases, particularly for patients unable to use metered dose inhalers ${ }^{(3,4)}$. Also it is effective in treatment of hyperkalemia in patients with chronic renal failure ${ }^{(5,6)}$. The usual dose of salbutamol nebules is $2.5-5 \mathrm{mg}$ in $2.5 \mathrm{ml}$ which can be diluted with sodium chloride $0.9 \%$ and given as single dose and can be repeated up to 12 times per day in hospital with monitoring ${ }^{(7)}$.

The aim of this study is to prepare a stable formula $\mathrm{F}$ for salbutamol sulphate nebules $0.1 \%$.The shelf life of this formula is to be determined and then subjected to a comparative study with a reference product, regarding their availability to lung.

\section{EXPERIMENTAL:}

\section{Materials and Instruments:}

Salbutamol sulphate powder and empty ampoules were kindly donated by SDI. Sodium unhydrous sulphate, chloroform and N, N- diethyl-P-phenylenediamine sulphate, methanol, sodium dodecy1 sulphate, potassium dihydrogenphosphate were from BDH, chemicals, Ltd, Pool, England. Sodium bicarbonate was from Evans, England. Potassium hexacyanoferrate and ortho phosphoric acid were from Riedel Dehaen, Hanover, Germany. Nitrogen gas was from Baghdad factory (SDI).

Ovens (Gallenhamp, model OV-160,England). Spectrophotometer(LKB Biochem,model 4049,England ). Vitalograph(model 520-336,Ireland),HPLCsystem consisted of Shimadzu chromatopac (C-RA,Japan), Shimadzu Liquid chromatograph (LC-BA,Japan),Shimadzu UV spectrophotometric detector (SPD-6A,Japan )and $4.6 \mathrm{~mm} \times 15 \mathrm{~cm}$,LC-18UItra sphere -I.P. column (Supel Co.,INC,Germany).

\section{METHODS :}

\section{* Stability Study :}

Several formulas of salbutamol nebules have been prepared by dissolving salbutamol sulphate powder in triple distilled water (table-1). The PH of the solutions was adjusted to 3.4 using different types of buffers, including :-

- $0.1 \mathrm{M}$ citric acid .

- $0.1 \mathrm{M}$ sodium citrate/ $0.1 \mathrm{M}$ HCL .

- $0.1 \mathrm{M}$ sodium hydrogen phosphate $/ 0.1 \mathrm{M}$ phosphoric acid .

- $0.1 \mathrm{M}$ sodium acetate $/ 0.1 \mathrm{M}$ acetic acid .

- $0.1 \mathrm{M} \mathrm{H}_{2} \mathrm{SO}_{4} / 0.1 \mathrm{M} \mathrm{NaOH}$. 
A high degree of clarification was achieved by filtration through $2 \mathrm{~mm}$ membrane filter before filling.

The prepared solution was filled under nitrogen gas in clear ,sterile, empty ampoules, which had been sealed by fusion method and sterilized by autoclaving. Each ampoule contains $2.5 \mathrm{ml}$ of the prepared solution. The shelf -life of all formulas was determined by incubation of ampoules in ovens at 50,60 and $70^{\circ} \mathrm{C}$ and for 120 days.

Ampoules contained $2.5 \mathrm{ml}$ of the tested solution were assayed for their drug content every 2 weeks, using the calorimetric method .

The observed first -order rate constants $(\mathrm{K})$ were obtained by linear regression analysis through utilizing the following equation:-

$\log \mathrm{Ct}=\log \mathrm{Co}-\mathrm{Kt} / 2.3303$

Where: $\mathrm{Ct}=$ concentration remaining at time $(\mathrm{t})$ and $\mathrm{C} 0=$ intial concentration .

\section{* Assay of Salbutamol Sulphate Nebules:}

A standard solution of salbutamol nebules in water $0.1 \%$ was mixed with $4 \mathrm{ml}$ of $5 \% \mathrm{w} / \mathrm{v}$ sodium hydrogen carbonate solution , $4 \mathrm{ml}$ of $0.1 \% \mathrm{w} / \mathrm{v} \mathrm{N}, \mathrm{N}-$ diethyl $-\mathrm{p}-$ phenylene diamine sulphate solution and $4 \mathrm{ml}$ of a freshly prepared $8 \% \mathrm{w} / \mathrm{v}$ potassium hexa cyano ferrate. Then salbutamol as a complex was extracted with chloroform.. The absorbance of the blue extract was measured at $620 \mathrm{~nm}$, using chloroform as a blank .

The same method was repeated for salbutamol sulphate nebules.Calculation of salbutamol sulphate concentration in each sample was obtained from the following equation ${ }^{(8)}$ :-

$\%$ Salbutamol sulphate $=\quad$ Absorbance of test $\quad \mathrm{x} 100$

Absorbance of standard

\section{Bioequivalency Study :}

\section{- Experimental Scheme:}

The bioequivalency of formula $\mathrm{F}$ and ventolin nebules was determined on ten healthy volunteers (6 females) between $20-35$ years old and weighing (50-90) $\mathrm{Kg}$. They were considered healthy on the basis of their history, and they had received light dinner and no drug at the study day. Each subject inhaled $2.5 \mathrm{ml}$ of formula $\mathrm{F}$ for 5 minutes then urine samples $(10 \mathrm{ml})$ were taken before as well as $1 / 2,1,2,4,6,10$ and 24hours after administration. Samples were stored in plastic tubes at $-20^{\circ} \mathrm{C}$ until the analysis. After 2 days the same volunteers had taken the same dose $2.5 \mathrm{mg} / 2.5 \mathrm{ml}$ of ventolin nebules (Allen and Hanburgs) and the procedure 
continued as for the prepared formula ${ }^{(9)}$.

* Calibration Curve And Chromatographic Conditions :

HPLC method was used to determine salbutamol sulphate in urine by preparation of series of dilution salbutamol sulphate in urine to give final concentrations ranging from 0.005 to $0.03 \mathrm{mg} / \mathrm{ml}$. The mobile phase was consisted of methanol: water $(60: 40)$ with sodium dodecyl sulphate $20 \mathrm{mmole}$ and potassium dihydrogen phosphate $10 \mathrm{mmole}$. The mobile phase was adjusted to $\mathrm{pH} 3$ with $1 \mathrm{M}$ phosphoric acid. A 20ML of urine sample was injected into the chromatograph of the HPLC with Suppl, LC-18 column. The flow rate was $1.0 \mathrm{ml} \mathrm{min}-1$ and the retention time of salbutamol was 3.6 $\min ^{(10)}$.

The absorbance of the effluent is monitored at $276 \mathrm{~nm}$ salbutamol was stable in urine when it was stored at $-20^{\circ} \mathrm{C}$ for up to one month. Quantitation of salbutamol sulphate nebules was accomplished by plotting the concentration in $\mathrm{mg} / \mathrm{ml}$ against peak height, as shown in fig. 1 .

\section{* Statistical Analysis :}

Student's t-test was used to examine the difference in the mean of the parameter tested. A p-value of $(p<0.05)$ was considered insignificant .

\section{RESULTS AND DISCUSSION :}

* Stability Study :

The degradation of salbutamol sulphate in all formulas follows first-order kinetics, since straight lines were obtained when the logarithm of percent remaining of salbutamol sulphate is plotted against time ,as shown in fig.2 for formula $\mathrm{F}$.

The degradation rate constants $(\mathrm{k})$ at 50,60 and $70^{\circ} \mathrm{C}$ for formula $\mathrm{F}$ were calculated from the slopes of the lines as shown in table 2. To determine the expiration date $(\mathrm{t} 10 \%)$, Arrhenius plot was utilized to predict the degradation rate constants at $25^{\circ} \mathrm{C}(\mathrm{k} 25)$, as shown in fig.3.

Results showed that the shelf-life of salbutamol sulphate in formula F was equal to 3.5 years, which indicates that formula $F$ is stable at the room temperature compared to other prepared formulas .

\section{*Bioequivalency Study Of Salbutamol Nebules :}

Methods of assessing the bioavailability of salbutamol to the lung following nebulization have been limited by analytical problems in measuring low plasma drug concentration and the lack of a suitable gama radio label inhaled marker. In addition, $90 \%$ of an inhaled dose is swallowed, so it is difficult to discriminate between the inhaled and swallowed fraction ${ }^{(11)}$.in this study we use 
an assay with sufficient sensitivity to measure urine concentrations of salbutamol sulphate after nebulization, because this method is simple ,noninvasive . Further more urinary excretion is the major rout of elimination of unchanged salbutamol and unaffected by the time interval between micturition $^{(12,13,14)}$.

Table- 3 shows the mean and standard deviation values of unchanged salbutamol excreted in time intervals for 10 normal subjects receiving $2.5 \mathrm{mg}$ of salbutamol sulphate, using formula $\mathrm{F}$ and ventolin nebules . While fig. 4 indicates the cumulative amount of unchanged salbutamol sulphate excreted during days of treatment .

Since salbutamol nebules has an onset of action within $5 \mathrm{~min}$.and shows a peak effect after $15 \mathrm{~min}$., so the fraction of dose recovered $30 \mathrm{~min}$, after nebulization is , therefore ,representative of the dose delivered to the site of action and is a measure of the bioequivalency of salbutamol to the lung ${ }^{(15)}$

The data indicated that there was no significant difference between the amount excreted from both formula $\mathrm{F}$ and ventolin nebules during the first $30 \mathrm{~min}$.and it was equal to $4.0( \pm 0.8) \%$ and $4.08( \pm 0.5) \%$ of the dose respectively .while the bioequivalency of formula $\mathrm{F}$ to the lung relative to that of ventolin nebules was equal to $98( \pm 5.2) \%$ for the same time.

The results suggest a successful utilization of formula $F$ in the preparation of salbutamol nebules. 
Table (1)

Schedule Of Different Formulation Of Salbutamol Sulphate as Nebules with Their Corresponding $K_{25}$ and $t_{10} \%$.

\begin{tabular}{|c|c|c|c|c|c|c|}
\hline Formula & $\begin{array}{c}\text { Salbutamol } \\
\text { Salphate } \\
\text { (mg) }\end{array}$ & $\begin{array}{c}\text { Buffer } \\
(\mathrm{PH}=\mathbf{3 . 4})\end{array}$ & $\begin{array}{c}\text { EDTA } \\
(\mathrm{gm})\end{array}$ & $\begin{array}{l}\text { Distilled } \\
\text { water } \\
\text { (ml) }\end{array}$ & $\begin{array}{c}\mathrm{K}_{25} \times 10^{-}-4 \\
\left(\text { day }^{-1}\right)\end{array}$ & T10\%(years) \\
\hline $\mathbf{A}$ & 2.5 & Citric acid & - & 2.5 & 1.26 & 2.29 \\
\hline B & 2.5 & Sodium citrate & - & 2.5 & 1.32 & 2.21 \\
\hline $\mathrm{C}$ & 2.5 & $\begin{array}{c}\text { Sodium } \\
\text { phosphate }\end{array}$ & - & 2.5 & 1.71 & 1.72 \\
\hline D & 2.5 & $\mathrm{H}_{2} \mathrm{SO}_{4}+\mathrm{NaOH}$ & - & 2.5 & 4.03 & 0.72 \\
\hline E & 2.5 & Sodium acetate & - & 2.5 & 10.9 & 0.27 \\
\hline F & 2.5 & Citric acid & 0.075 & 2.5 & 0.84 & 3.47 \\
\hline
\end{tabular}

Table(2)

Degradation Rate Constants (k) Of Salbutamol Salphate In Formula $\mathrm{F}$ at 50,60 and $70^{\circ} \mathrm{C}$.

\begin{tabular}{|c|c|c|c|}
\hline \multirow{4}{*}{ Formula } & Temperature & $\begin{array}{c}\text { Kobs } \mathbf{x} 10^{-4} \\
\left(\text { day }^{-1}\right)\end{array}$ & Log K obs( day $\left.^{-1}\right)$ \\
\cline { 2 - 4 } & $50^{\circ} \mathrm{C}$ & 1.7 & -3.76 \\
\cline { 2 - 4 } & $60^{\circ} \mathrm{C}$ & 2.7 & -3.56 \\
\cline { 2 - 4 } & $70^{\circ} \mathrm{C}$ & 4.1 & -3.38 \\
\hline
\end{tabular}


Table (3)

Mean \pm SD of Urinary Excretion of Unchanged Salbutamol Sulphate and Other Pharmacokinetic Parameters.

\begin{tabular}{|c|c|c|}
\hline \multirow{2}{*}{ Time (hr) } & $\begin{array}{c}\text { Amount of unchanged salbutamol excreted in } \\
\text { time interval (mg). } \\
\text { Vent Olin nebulas }\end{array}$ \\
\cline { 2 - 3 } & Formula F & $0.102 \pm 0.15$ \\
\hline $0-0.5$ & $0.1 \pm 0.25$ & $0.099 \pm 0.12$ \\
\hline $0.5-1$ & $0.091 \pm 0.3$ & $0.15 \pm 0.02$ \\
\hline $1-2$ & $0.13 \pm 0.02$ & $0.09 \pm 0.001$ \\
\hline $2-4$ & $0.14 \pm 0.008$ & $0.12 \pm 0.003$ \\
\hline $4-6$ & $0.06 \pm 0.001$ & - \\
\hline $6-8$ & - & - \\
\hline $8-10$ & - & $0.56 \pm 0.31$ \\
\hline Total(mg) & $0.52 \pm 0.25$ & $22.44 \pm 5.1$ \\
\hline $\begin{array}{c}\text { Cumulative } \\
\text { recovery (\%) }\end{array}$ & $20.80 \pm 4.1$ & 0.25 \\
\hline *Ke(hr) & & 2.77 \\
\hline$* *$ (hr) & 0.31 & \\
\hline
\end{tabular}

*Ke was directly calculated from figure 4. ** $t_{1 / 2}$ is determined From the following relation : $1 / 2=0.693 / \mathrm{Ke}$ 


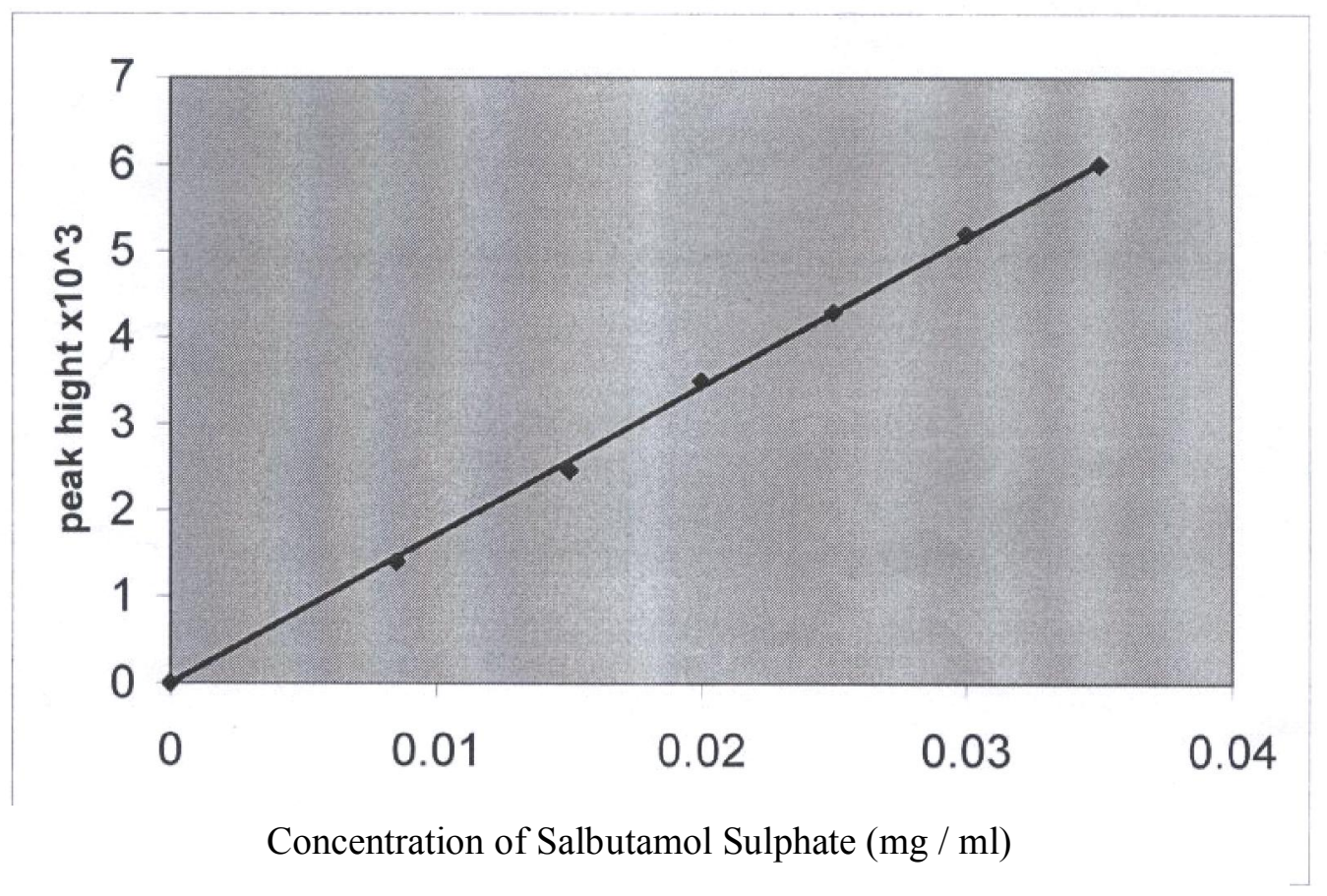

Figure (1)

Calibration curve of salbutamol sulphate is urine

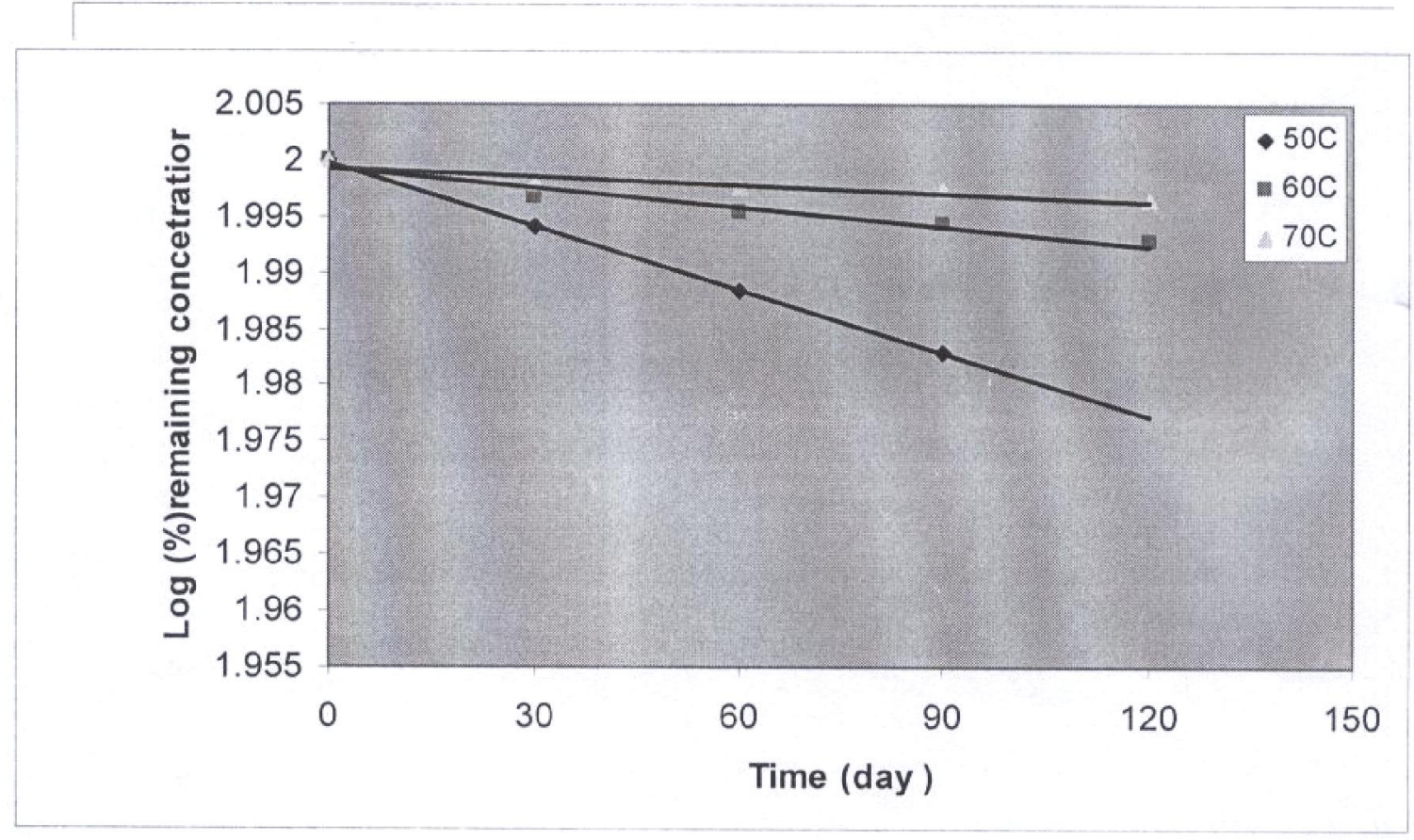

Figure (2)

Degradation of salbutamol sulphte at 50,60 and $70{ }^{\circ} \mathrm{C}$ 


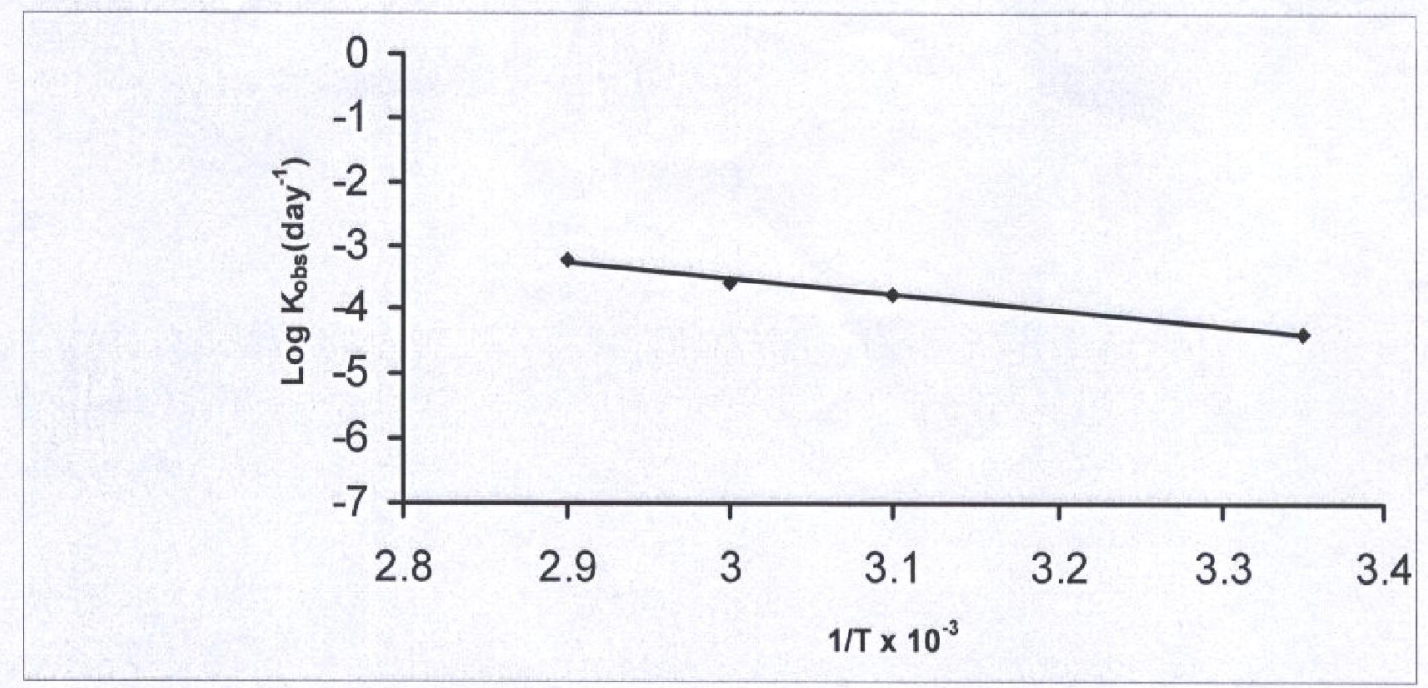

Figure (3)

Arrhenius plot for shelf life estimation of salbutomol sulphate Nebules

(formula F )

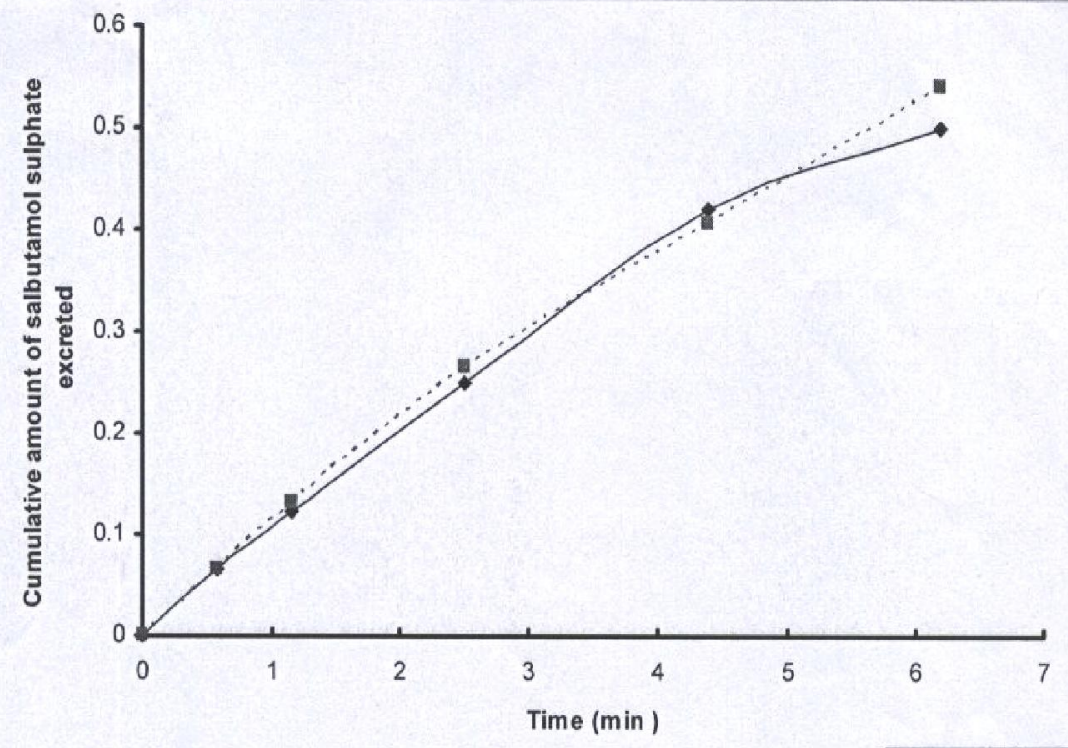

$\longrightarrow$ Formula $\mathrm{F}$

.....-Ventolin nebule

Figure (4)Cumulative amount of unchanged salbutamol sulphate excreted following nebulization of formulas $\mathrm{F}$ and Ventolin nebulas 


\section{References:}

1. Richard, A.H., Pamela C.C. and Marry, J.M. Pharmacology, 2000, Ch . 21,p . 218.

2. Martindale Extrapharmacopieaz, 32 ed., 1999,Vol .I, p.759.

3. Glenn, A.J and Gregory, M.P .High - performance liquid chromatographic assay for the simultaneous determination of ipraropium bromide, fenoterol, salbutamol and terbutaline in nebulizer solution. Pharmaceutical and Biomedical analysis J., 1994,12(6), 825-832.

4. Abroug ,F.,Nouira, S,Behir ,A ., Boujdar R.,Elatrous,S.and Bouchoucha ,S.A controlled trial of nebulized salbutamol and adrenaline in acute severe asthma .Intensive Care Med., (Jan.)1995,12(1),18-23.

5. Liou,H.H. Hypokalemic effects of intravenous infusion or nebulization of salbutamol in patients with chronic renal failure : comparative study Am.J. kidney Dis ., (Feb.)1994,349,301-5.

6. Montoliu,J.,Almirall,J.,ponz,E.,Campistol,J.M.and Revert,L.Treatment of hyperkalaemia in renal failure with salbutamol Inhalation. J. Inter .Med., (Jul.)1990,228(1),35-7.

7. Infomations supplied by sara barcham, Medical information Advisor, Glaxo Welcome,U.K., 1997,16.6.

8. BP, VOL.II, HMSO, United Kingdom,1993, P. 845, A 183, A 191.

9. Michael, Hand Henry, C. Determination of the relative bioavailability of salbutamol to the lung following inhalation. Br. J. Clin. Pharmacy. 1992,34,311315 .

10.Jarvie, D.R., Thompsom, A.M. and Dyson, E,H.Laboratory and clinical features of self-poisoning with salbutamol and terbutaline .Clin. Chem.Acta, 1987,168,313-322.

11. Newman, S .P., Pavia. D. Moren, F., Sheahan ,N.F.and Clark, S.W. Deposition of pressurized aerosols in the hyman respiratory tract . Thorax, 1981,36,52-55.

12. Lewis ,L.D., Essex , E., Mclaren , M.and Cochrane, G.M.plasma concentrations of salbutamol in acute severe asthmatic .Asut .N.Z.J.Med ., 1990,20,204-207.

13. Horn ,C.R.,Essex ,E.,Hill, P. and Cochrane, G.M.dose urinary salbutamol reflect compliance with aerodol regimen in patients with asthma .Res.P.Med., 1990,83,15-18.

14. Jaccobson,G.A.,Peterson,G.M.and Mclean, S.Investigation of urinary levels of salbutamol in asthmatic patients receiving inhaled therapy .J.of Clinical Pharmacy and Therapeutics , 1997,22,119-126.

15. Hetzel ,M.R.and Clarhe, T.J.H.comparison of intravenous and aerosol salbutamol .Br.Med .J. 1976,2,919. 